\title{
The safe ethanol dose: a review of epidemiological data for the last six decades
}

\author{
Menizibeya Welcome Osain*, Vladimir Pereverzev Alekseevic \\ From $1^{\text {st }}$ International Congress on Neurobiology and Clinical Psychopharmacology and European \\ Psychiatric Association Conference on Treatment Guidance \\ Thessaloniki, Greece. 19-22 November 2009
}

\section{Background}

Alcohol use as a risk for health enormously contributes to the burden of disease world-wide. According to experts' estimation approximately $4 \%$ of global burden of disease is associated with alcohol misuse. Alcohol is involved in about $40 \%$ of motor vehicle accidents, 47 $70 \%$ of homicides, $25-37 \%$ of suicides. Although 1-2 standard drinks/per day (with 1-2 free-alcohol days) has been recommended (especially for adults) as a prophylactic measure for ischemic heart disease, there is a paucity of data concerning the dose time dependent effect of alcohol use on psycho-physiological functions. Most of the problems related with alcohol use have been largely pronounced among the young adult population. Since in most cases, the effects of alcohol use are rather than harmful, there is need to determine a long-term "relatively" safe dose of alcoholic beverages.

\section{Materials and methods}

Our data (based on the psycho-physiological functions of university students for a 4 years period of study and follow-up), as well as current epidemiological and clinical data on the dose-time response effect of alcohol use for the last six decades were examined. All alcohol doses are given in values of pure ethanol.

\section{Results}

There is necessity of normalizing, not only the daily dose of alcoholic drinks, but also the monthly total dose.

\section{Conclusions}

We therefore, formulate the concept of relatively safe per session and monthly dose of alcoholic beverages, which must not exceed $27 \mathrm{ml}$ and $40 \mathrm{ml}$ for males

Department of Human Physiology, Belarusian state medical university, Minsk, Belarus respectively and not more than $24 \mathrm{ml}$ and $31 \mathrm{ml}$ respectively for females.

Published: 22 April 2010

doi:10.1186/1744-859X-9-S1-S217

Cite this article as: Osain and Alekseevic: The safe ethanol dose: a review of epidemiological data for the last six decades. Annals of General Psychiatry 2010 9(Suppl 1):S217.
Submit your next manuscript to BioMed Central and take full advantage of:

- Convenient online submission

- Thorough peer review

- No space constraints or color figure charges

- Immediate publication on acceptance

- Inclusion in PubMed, CAS, Scopus and Google Scholar

- Research which is freely available for redistribution

Submit your manuscript at www biomedcentral.com/submit
C Biomed Central 